\title{
Sericin inhibits MDA-MB-468 cell proliferation via the PI3K/Akt pathway in triple-negative breast cancer
}

\author{
LIN NIU $^{1 *}$, SONGHE YANG $^{1 *}$, XUEYING ZHAO ${ }^{2}$, XIAOCHAO LIU ${ }^{1}$, LINA SI $^{1}$, MENG WEI $^{1}$, \\ LEI LIU ${ }^{2}$, LUYANG CHENG ${ }^{2}$, YUEBING QIAO ${ }^{1}$ and ZHIHONG CHEN ${ }^{1}$
}

\author{
Departments of ${ }^{1}$ Human Anatomy and ${ }^{2}$ Immunology, Chengde Medical University, Chengde, Hebei 067000, P.R. China
}

Received July 26, 2020; Accepted November 25, 2020

DOI: $10.3892 / \mathrm{mmr} .2020 .11779$

\begin{abstract}
Triple negative breast cancer (TNBC) is a subtype of breast cancer characterized by an aggressive histology and poor prognosis, with limited treatment options in the clinic. In the present study, the effect of sericin, as an anti-cancer drug, on TNBC cell proliferation was investigated using a MTT assay, a colony formation assay and immunocytochemistry staining of Ki67. Results from the flow cytometry demonstrated that sericin induced $G_{0} / G_{1}$ cell cycle arrest and promoted cellular apoptosis. Cell cycle and apoptosis-related proteins were detected via western blot analysis. Immunocytochemistry staining identified that P21 was translocated into the nucleus. Additionally, several pathways were significantly enriched in TNBC based on the Gene Expression Omnibus database, with the most prominent pathway being the PI3K/Akt signaling pathway. In TNBC MDA-MB-468 cells, sericin suppressed the PI3K/Akt pathway. All these findings suggested that sericin served a critical role in suppressing TNBC cell proliferation, inducing cell cycle arrest and promoting cellular apoptosis. The results indicated that the underlying molecular mechanism was, at least partially, via the downregulation of the PI3K/Akt signaling pathway.
\end{abstract}

\section{Introduction}

Triple-negative breast cancer (TNBC) is a heterogeneous type of breast cancer characterized by the absent expression of estrogen receptor (ER), progesterone receptor (PR) and human epidermal growth factor receptor 2 (HER2) (1). In the clinic,

Correspondence to: Professor Zhihong Chen or Professor Yuebing Qiao, Department of Human Anatomy, Chengde Medical University, Anyuan Road, Shuangqiao, Chengde, Hebei 067000, P.R. China

E-mail: czh1971@126.com

E-mail: qiaoyuebing@126.com

*Contributed equally

Key words: sericin, MDA-MB-468, cell proliferation, PI3K/Akt signaling pathway, triple negative breast cancer
TNBC is known to be an aggressive subtype of breast cancer, with a higher rate of relapse than the ER/PR- and HER2-positive breast cancer types (2). Patients with TNBC tend to have poorer clinical prognosis compared with other breast cancer types (3). Moreover, $<30 \%$ of women diagnosed with metastatic TNBC survive five years, and virtually all the female metastatic TNBC cases succumb to the diseases (4). To date, no targeted therapies have been recommended for the treatment of TNBC, while chemotherapy remains the primary treatment modality for TNBC. However, traditional first-line drugs, such as paclitaxel, applied to treat breast cancer fail to provide satisfactory therapeutic effects when used in treating TNBC (5). Therefore, it is of great significance to develop novel therapeutic strategies for TNBC.

Recently, natural agents have been increasingly investigated as an effective chemotherapy strategy for cancer, with relatively low toxicity (6). Sericin, a natural macromolecular protein from silkworm cocoons, accounts for $10-35 \%$ of the total silk protein (7). Sericin is produced in the middle silk gland, and has been widely used in the biomedical field as anti-inflammatory drug, antioxidant, enzyme immobilizing factor, cell culture medium supplement, dietary supplement and/or biomaterial for drug and gene delivery (8-11). Our previous study reported that sericin could prevent kidney injuries in rats with diabetic nephropathy, by inhibiting the activation of the transforming growth factor- $\beta 1 / \mathrm{Smad} 3$ signal pathway and reducing glomerulosclerosis and renal interstitial fibrosis in kidney (12). Moreover, sericin has been revealed to decrease hippocampal neuronal apoptosis by activating the Akt signaling pathway in diabetic rats (13). Sericin has also been shown to improve spermatogenesis by regulating the growth hormone/insulin-like growth factor- 1 axis and to protect the reproductive ability against diabetes-induced damages (14). Furthermore, several studies have reported that sericin could exert antitumor effects in various tumor types, including gastric carcinoma (15), colon carcinoma (16-18), skin carcinoma $(19,20)$, squamous carcinoma, breast adenocarcinoma and tongue carcinoma (21). However, the effects of sericin in TNBC and the underlying molecular mechanisms remain to be further elucidated.

In the present study, the sericin-induced antitumor activity in TNBC MDA-MB-468 cells was investigated. The effects of sericin on the cell proliferation, cell cycle and cellular apoptosis were analyzed. Bioinformatics analysis was performed to predict the signaling pathway involved in TNBC pathogenesis. 
All the findings may provide scientific evidence for the application of sericin in the clinical treatment of TNBC.

\section{Materials and methods}

Cell and cell culture. Human TNBC cell lines (MDA-MB-468 and MDA-MB-453), a non-TNBC MCF-7 cell line and a normal breast epithelial MCF-10A cell line were purchased from Procell Life Science \& Technology Co., Ltd. MDA-MB-468 and MDA-MB-453 cells were cultured with the Leibovitz's L-15 medium (cat. no. CM10045; Beijing Zhongke Maichen Technology Co., Ltd.) containing 10\% fetal bovine serum (cat. no. 04-001-1A; Biological Industries) and $1 \%$ penicillin-streptomycin (cat. no. P1400-100ML; Beijing Solarbio Science \& Technology Co., Ltd.) at $37^{\circ} \mathrm{C}$ without $\mathrm{CO}_{2}$. MCF-7 and MCF-10A cells were cultured with DMEM (cat. no. C11995500BT; Gibco; Thermo Fisher Scientific, Inc.) containing 10\% fetal bovine serum (cat. no. 04-001-1A; BioInd, Israel) and $1 \%$ penicillin-streptomycin (cat. no. P1400-100ML, Solarbio, Beijing Solarbio Science \& Technology Co., Ltd.) in a $37^{\circ} \mathrm{C}, 5 \% \mathrm{CO}_{2}$ incubator. The cells were passaged every 4-5 days using $0.25 \%$ Trypsin-EDTA (v/v) (cat. no. 25200-056; Gibco; Thermo Fisher Scientific, Inc.).

MTT assay. Cell viability was assessed with the MTT assay (cat. no. M6180; Biotopped). The cells were seeded into the 96-well plate, at density of $1.0 \times 10^{4}$ cells/well. MDA-MB-468, MDA-MB-453 and MCF-10A cells were treated with sericin (dissolved with complete medium; cat. no. S5201; Sigma-Aldrich; Merck KGaA) at indicated concentrations $(0,0.5,1,2,4,8$ and $16 \mathrm{mg} / \mathrm{ml})$ at $37^{\circ} \mathrm{C}$ for $24 \mathrm{~h}$. MCF-7 cells were treated with sericin $(0,2,4$ and $8 \mathrm{mg} / \mathrm{ml})$ at $37^{\circ} \mathrm{C}$ for $24 \mathrm{~h}$. The culture medium was then discarded. Complete $100 \mu \mathrm{l}$ culture medium was mixed with $10 \%$ MTT solution, which was added into each well, to incubate the cells at $37^{\circ} \mathrm{C}$ for $4 \mathrm{~h}$. After discarding the medium, formazan crystals were dissolved with $100 \mu 1$ DMSO. Absorbance at $570 \mathrm{~nm}$ was measured with a microplate reader and the $\mathrm{IC}_{50}$ was calculated using GraphPad prism 7.0 (GraphPad Software, Inc.).

Colony formation assay. MDA-MB-468 cells were seeded into the 6 -well plates at a density of $2.0 \times 10^{4}$ cells $/$ well, and were incubated at $37^{\circ} \mathrm{C}$ for $48 \mathrm{~h}$. After adhering, the cells were treated with sericin at indicated concentrations $(0,2,4$ and $8 \mathrm{mg} / \mathrm{ml}$ ) for $24 \mathrm{~h}$ at $37^{\circ} \mathrm{C}$, and then cultured with L-15 complete medium at $37^{\circ} \mathrm{C}$ for 14 days. After fixing with $4 \%$ paraformaldehyde at $4^{\circ} \mathrm{C}$ for $30 \mathrm{~min}$, the cell colonies were stained with $0.1 \%$ crystal violet for $20 \mathrm{~min}$ at room temperature. The number of colonies containing $\geq 50$ cells was counted under a light microscope (magnification, $\mathrm{x} 40$ ), and the cell colonies were imaged.

Flow cytometry. Cell cycle progression and apoptosis (early and late apoptosis) were detected via flow cytometry. MDA-MB-468 cells were treated with sericin at $0,2,4$ and $8 \mathrm{mg} / \mathrm{ml}$ for $24 \mathrm{~h}$ at $37^{\circ} \mathrm{C}$. Subsequently, $1 \times 10^{6}$ cells treated with sericin were harvested and stained with Pharmingen ${ }^{\mathrm{TM}}$ PI/RNase Staining buffer (cat. no. 550825; BD Biosciences) or FITC Annexin V Apoptosis Detection Kit I (cat. no. 556547; BD Biosciences) for 15-20 min at room temperature according to the manufacturer's instructions. After incubation for $30 \mathrm{~min}$, the cells were detected using a Coulter ELITEesp flow cytometer (Beckman Coulter, Inc.) and data analysis was performed using FloMax 2.7 software (Sysmex Partec).

Immunocytochemistry. Immunocytochemistry was performed with the StreptAvidin-Biotin Complex kit (cat. no. SP-9000; OriGene Technologies, Inc.). MDA-MB-468 cells were seeded into the 24-well plates at a density of $5 \times 10^{4}$ cells $/ \mathrm{ml}$, which were treated with sericin at $0,2,4$ and $8 \mathrm{mg} / \mathrm{ml}$ for $24 \mathrm{~h}$ at $37^{\circ} \mathrm{C}$. The cells were fixed with $4 \%$ paraformaldehyde at $4^{\circ} \mathrm{C}$ for $30 \mathrm{~min}$ and then permeabilized with $0.1 \%$ Triton X-100 in PBS at $4^{\circ} \mathrm{C}$ for $10 \mathrm{~min}$. Quenching of endogenous peroxidase was achieved using $3 \% \mathrm{H}_{2} \mathrm{O}_{2}$ at $37^{\circ} \mathrm{C}$ for $10 \mathrm{~min}$. After blocking with $10 \%$ goat serum (cat. no. SL038; Beijing Solarbio Science \& Technology Co., Ltd.) at room temperature for $30 \mathrm{~min}$, the cells were incubated with rabbit anti-human anti-P21 (1:300: Cat. no. ab109520; Abcam) and rabbit anti-human anti-Ki67 (1:100; cat. no. ZA-0502; OriGene Technologies, Inc.) primary antibodies at $4{ }^{\circ} \mathrm{C}$ overnight. The goat anti-rabbit secondary antibody $(1: 10,000$; cat. no. SP-9000; OriGene Technologies, Inc.) was added to the cells at $37^{\circ} \mathrm{C}$ for $30 \mathrm{~min}$. Chromogenic development was performed using the DAB kit (cat. no. ZLI-9017; OriGene Technologies, Inc.). Then, the cells were counterstained with hematoxylin for $2 \mathrm{~min}$ at room temperature, followed by observation under a light microscope (cat. no. BX43; Olympus Corporation; magnification, $\mathrm{x} 100$ or $\mathrm{x} 400$ ).

Western blot analysis. MDA-MB-468 cells were lysed with RIPA lysis buffer (cat. no. R0020-100ML; Beijing Solarbio Science \& Technology Co., Ltd.) and were centrifuged at $7,500 \mathrm{x} \mathrm{g}$ at $4^{\circ} \mathrm{C}$ for $15 \mathrm{~min}$. Protein concentration was determined using the BCA Protein Assay kit (cat. no. PC0020-500; Beijing Solarbio Science \& Technology Co., Ltd.). Equal amounts of protein from whole-cell lysates $(30 \mu \mathrm{g})$ were separated on $10 \%$ SDS-PAGE, which were then transferred onto the PVDF membrane (cat. no. IPVH00010; EMD Millipore). After blocking with skimmed milk in TBS $+0.1 \%$ Tween-20 for $3 \mathrm{~h}$ at room temperature, the membrane was incubated with mouse anti-human anti-cyclin D1 (1:4,000: Cat. no. 60186-1-1g; ProteinTech Group, Inc.), rabbit anti-human anti-Cdk4 (1:2,000; cat. no. ab108357; Abcam), rabbit anti-human anti-E2F transcription factor $3(\mathrm{E} 2 \mathrm{~F} 3$; 1:1,000; cat. no. ab50917; Abcam), rabbit anti-human anti-P21 (1:5,000; cat. no. ab109520; Abcam), rabbit anti-human anti-P27 (1:5,000; cat. no. ab32034; Abcam), rabbit anti-human anti-Bax (1:500; cat. no. ab53154; Abcam), rabbit anti-human anti-Bcl-2 (1:500; cat. no. ab59348; Abcam), rabbit anti-human anti-cytochrome $c$ (Cyto-C; 1:5,000; cat. no. ab133504; Abcam), rabbit anti-human anti-PI3K (1:500; cat. no. BS3678; Bioworld Technology, Inc.), rabbit anti-human anti-Akt (1:10,000; cat. no. ab179463; Abcam), rabbit anti-human anti-phosphorylated (p)-Akt (1:500; cat. no. BS4006; Bioworld Technology, Inc.), rabbit anti-human anti-Heat shock protein 90 (HSP90; 1:10,000; cat. no. ab13495; Abcam) and rabbit anti-human anti-GAPDH (1:8,000; cat. no. AP0063; Bioworld Technology, Inc.) primary antibodies at $4^{\circ} \mathrm{C}$ overnight. Then, the membrane was incubated with HRP-conjugated anti-mouse (1:5,000; cat. no. ab6789; Abcam) or anti-rabbit (1:5,000; 
cat. no. ab205718; Abcam) secondary antibodies for $90 \mathrm{~min}$ at room temperature. Immune-reactive proteins were visualized with the ECL luminescence reagent (cat. no. MA0186; Dalian Meilun Biology Technology Co., Ltd.). The bands were detected with a Tanon 5200 imaging system (Tanon Science and Technology Co., Ltd.), and the integrated density was quantified using ImageJ 1.52a software (National Institutes of Health).

Data availability. GSE112825 (22) and GSE76124 (23), containing information on the mRNA expression levels of normal mammary and TNBC tissue, were obtained from the Gene Expression Omnibus (GEO) database (https://www.ncbi. nlm.nih.gov/geo/) (24). The GSE112825 dataset contained 109 normal mammary tissue samples and the GSE76124 dataset contained 198 TNBC tissue samples, based on the GPL570 [HG-U133_Plus_2] Affymetrix Human Genome U133 Plus 2.0 arrays platform (Affymetrix; Thermo Fisher Scientific, Inc.). These two datasets were imported into R software, version 3.6.1 (https://www.R-project.org/) for quality assessment. To eliminate batch effects, 'sva' and 'limma' R packages were applied for batch effect normalization. Differential expression analysis on datasets was then performed using the limma package in R. $\mid \log _{2}$ (fold-change) $\mid>2.0$ and $\mathrm{P}<0.05$ were set as cutoffs for differentially expressed genes.

Gene ontology (GO) and kyoto encyclopedia of genes and genomes (KEGG) pathway analysis. GO annotation analysis and KEGG pathway enrichment analysis of the aforementioned differentially expressed genes were performed using the Database for Annotation, Visualization and Integrated Discovery (DAVID) v6.8 online tool (https://david.ncifcrf. gov/). The background was set as Homo sapiens. $\mathrm{P}<0.05$ was considered to indicate a statistically significant difference. The GO analysis included the following three ontologies: Biological process (BP), cellular component $(\mathrm{CC})$ and molecular function (MF). Moreover, the reliability of the KEGG analysis was validated using the gene set enrichment analysis (GSEA) software v3.0 (http://www.broadinstitute.org/gsea). Results for which the normalized enrichment score (NES) absolute value was $>1$, nominal P-value was $<0.05$ and false discovery rate q-value was $<0.25$ were considered as significant. Lists of genes involved in various pathways were acquired from the KEGG database (25), and the most critical pathway related genes were selected to plot a diagram.

Kaplan-Meier plotter. The overall survival curves of patients with breast cancer with different expression levels of the most critical pathway-associated genes were constructed using the online Kaplan-Meier Plotter tool (https://www.kmplot. com) (26). A log-rank test, the only available method in this online analysis tool, was calculated and differences with $\mathrm{P}<0.05$ were considered as statistically significant. The Kaplan-Meier survival curves were downloaded from the website and the number-at-risk was indicated below the main plot.

Statistical analysis. Data are presented as the mean \pm SD. Each experiment was carried out three times. Statistical significance was assessed with the one-way ANOVA or the independent-samples t-test and the pairwise comparisons were performed with Bonferroni correction, using the SPSS software (v19; IBM Corp.). GraphPad Prism software (v7.0; GraphPad Software, Inc.) was used for illustration. $\mathrm{P}<0.05$ was considered to indicate a statistically significant difference.

\section{Results}

Sericin inhibits proliferation of TNBC cells. The effects of sericin on the proliferation of human TNBC MDA-MB-468 and MDA-MB-453 cells, non-TNBC MCF-7 cells and normal breast epithelial MCF-10A cells were investigated. The cells were exposed to sericin at indicated concentrations for $24 \mathrm{~h}$, and cell viability was assessed with the MTT assay. Sericin treatment inhibited the viability of both MDA-MB-468 $(\mathrm{F}=74.516 ; \mathrm{P}<0.001)$ and MDA-MB-453 ( $\mathrm{F}=23.150 ; \mathrm{P}<0.001)$ cells, in a dose-dependent manner (Fig. 1A and B), suggesting that the human TNBC cells showed sensitivity to sericin. Moreover, the effects of sericin on MDA-MB-468 cells $\left(\mathrm{IC}_{50}=10.67 \mathrm{mg} / \mathrm{ml}\right)$ were slightly more apparent compared with the MDA-MB-453 cells $\left(\mathrm{IC}_{50}=12.06 \mathrm{mg} / \mathrm{ml}\right)$. Sericin had less of a growth inhibiting effect on non-TNBC MCF-7 cells $(\mathrm{F}=0.663 ; \mathrm{P}=0.587)$ and normal breast epithelial MCF-10A cells $(\mathrm{F}=1.964 ; \mathrm{P}=0.117)$ (Fig. $1 \mathrm{C}$ and $\mathrm{D})$. According to the findings from the MTT assay in MDA-MB-468 cells, the $1 / 5 \mathrm{IC}_{50}, 2 / 5 \mathrm{IC}_{50}$ and $4 / 5 \mathrm{IC}_{50}$ doses of sericin, serving as low, middle and high concentrations, were used in the subsequent experiments.

The results suggested that sericin significantly suppressed the colony formation of MDA-MB-468 cells, in a dosedependent manner $(\mathrm{F}=81.602$; $\mathrm{P}<0.001$; Fig. $1 \mathrm{E}$ and $\mathrm{F})$. The clone number for the cells treated with sericin at concentrations of 8,4 and $2 \mathrm{mg} / \mathrm{ml}$ were $215.000 \pm 8.544(\mathrm{P}<0.001)$, $313.333 \pm 23.116(\mathrm{P}<0.001)$ and $328.667 \pm 17.215(\mathrm{P}<0.001)$, respectively, which were lower compared with those of the cells treated with $0 \mathrm{mg} / \mathrm{ml}$ sericin $(459.667 \pm 24.132)$. Similar results were observed in the immunocytochemistry assay. The Ki67 staining identified that MDA-MB-468 cell proliferation was significantly inhibited by sericin treatments in a dose-dependent manner ( $\mathrm{F}=76.470$; $\mathrm{P}<0.001$; Fig. $1 \mathrm{G}$ and $\mathrm{H}$ ). Therefore, the findings suggested that sericin may only inhibit the proliferation of TNBC cells.

Sericin induces cell cycle arrest at the $G_{0} / G_{I}$ phase. To investigate the effects of sericin on the cell cycle of MDA-MB-468 cells, flow cytometry was performed. The results demonstrated that the sericin treatment led to an increased portion of cells at the $G_{0} / G_{1}$ phase $(F=32.131 ; P<0.001)$ and a reduction at the $\mathrm{S}$ phase $(\mathrm{F}=38.818 ; \mathrm{P}<0.001)$, in a dose-dependent manner (Fig. 2A and B). There was no statistical significance among the cells treated with $0,2,4$ and $8 \mathrm{mg} / \mathrm{ml}$ sericin at the $\mathrm{G}_{2}$ phase $(\mathrm{F}=2.168 ; \mathrm{P}=0.17)$. Furthermore, to validate the effects of sericin on cell cycle progression, the expression levels of cell cycle-regulated proteins were detected via western blot analysis. The results suggested that sericin treatment significantly decreased the expression levels of cyclin D1 $(\mathrm{F}=35.866 ; \mathrm{P}<0.001), \mathrm{Cdk} 4(\mathrm{~F}=163.359 ; \mathrm{P}<0.001)$ and $\mathrm{E} 2 \mathrm{~F} 3$ $(\mathrm{F}=257.478 ; \mathrm{P}<0.001)$, while increased the expression levels of $\mathrm{P} 21(\mathrm{~F}=80.107 ; \mathrm{P}<0.001)$ and $\mathrm{P} 27(\mathrm{~F}=471.443 ; \mathrm{P}<0.001)$ (Fig. 2C and D). 
A

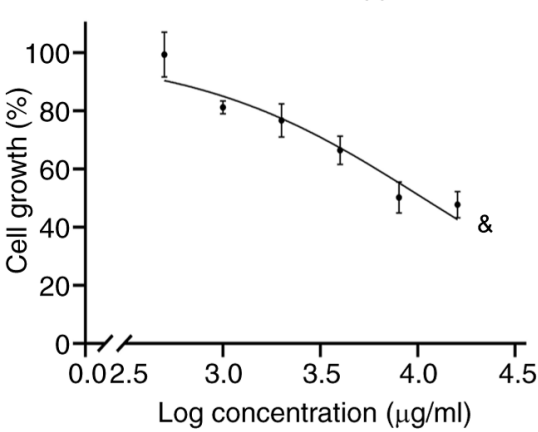

D

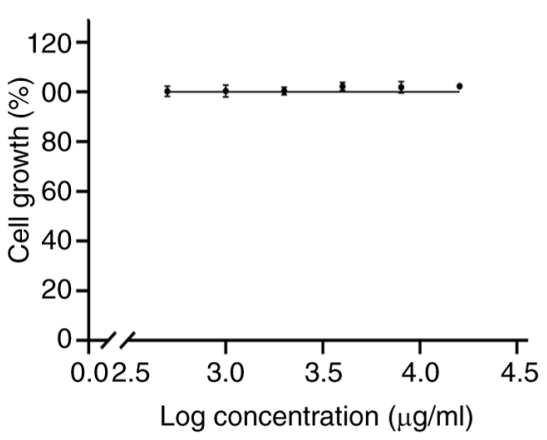

G

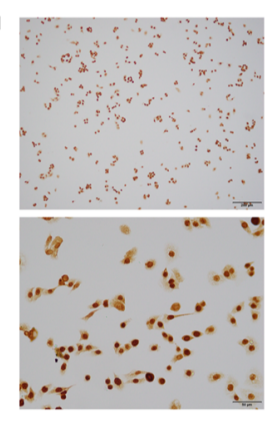

$0 \mathrm{mg} / \mathrm{ml}$

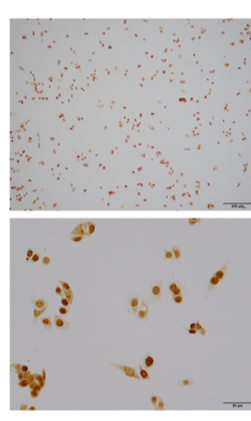

$2 \mathrm{mg} / \mathrm{ml}$
B

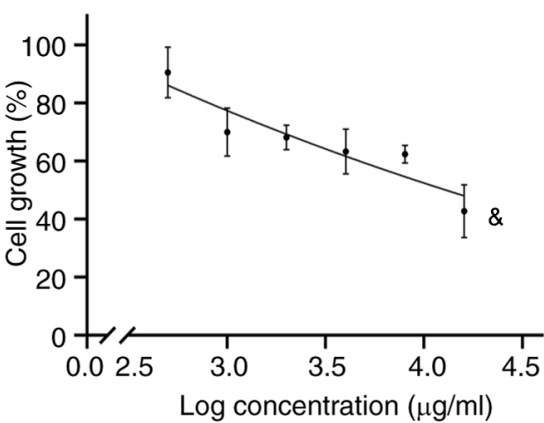

E
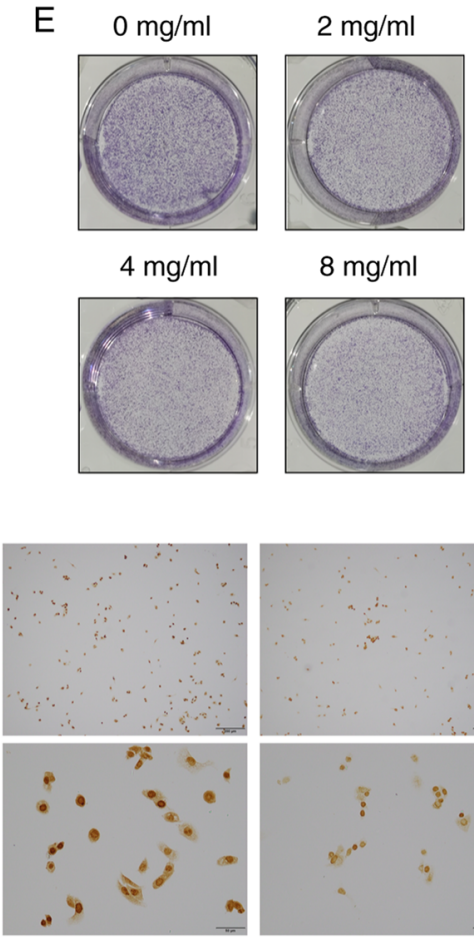

$4 \mathrm{mg} / \mathrm{ml}$

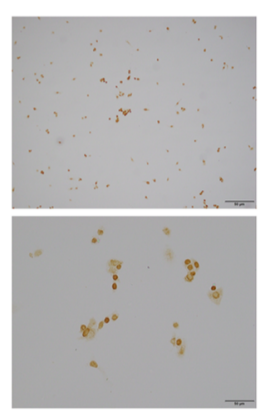

$8 \mathrm{mg} / \mathrm{ml}$
C
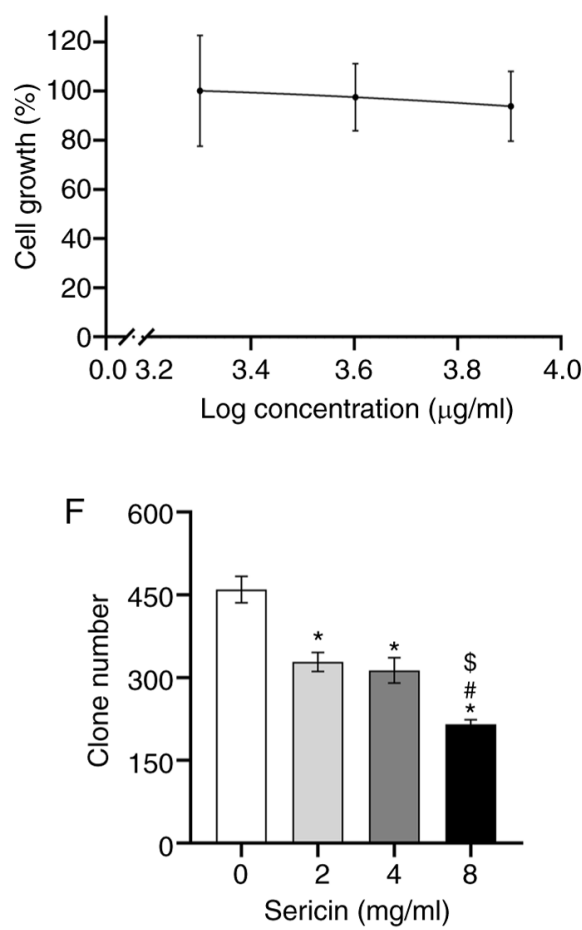

$\mathrm{H}$

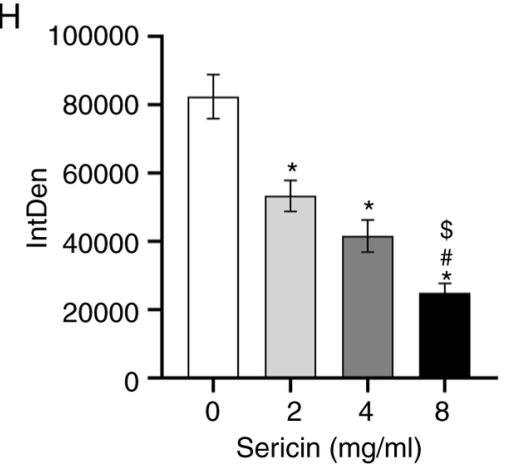

Figure 1. Sericin inhibits TNBC cell proliferation. TNBC (A) MDA-MB-468 cells and (B) MDA-MB-453 cells, (C) non-TNBC MCF-7 cells and (D) normal breast epithelial MCF-10A cells were treated with sericin at indicated concentrations. The $0 \mathrm{mg} / \mathrm{ml}$ concentration was not shown due to the application of the $-\log _{10}$ scale. ${ }^{\&} \mathrm{P}<0.05$. (E) Colony formation assays for the indicated groups. (F) Quantitative histogram of clone numbers. (G) Representative immunocytochemistry staining for Ki67 in MDA-MB-468 cells after sericin treatment. Magnification, x100 or x400. (H) Quantitative analysis of immunocytochemistry staining. ${ }^{*} \mathrm{P}<0.05$ vs. $0 \mathrm{mg} / \mathrm{ml}$ group; ${ }^{\#} \mathrm{P}<0.05 \mathrm{vs} .2 \mathrm{mg} / \mathrm{ml}$ group; ${ }^{\$} \mathrm{P}<0.05 \mathrm{vs} .4 \mathrm{mg} / \mathrm{ml}$ group. TNBC, triple negative breast cancer.

Immunocytochemistry was also conducted to further detect the effects of sericin on the MDA-MB-468 cells. The results demonstrated that $\mathrm{P} 21$ was translocated into the nucleus (Fig. 2E), and both the nuclear ( $\mathrm{t}=-10.918 ; \mathrm{P}<0.001)$ and total $(\mathrm{t}=-7.948 ; \mathrm{P}=0.001)$ expressions levels of $\mathrm{P} 21$ were increased in the cells treated with $8 \mathrm{mg} / \mathrm{ml}$ sericin, compared with the cells in $0 \mathrm{mg} / \mathrm{ml}$ sericin group (Fig. 2F). These results suggested that sericin could induce cell cycle arrest at the $\mathrm{G}_{0} / \mathrm{G}_{1}$ phase.

Sericin induces apoptosis in MDA-MB-468 cells. To further investigate the effects of sericin on the MDA-MB-468 cells, cellular apoptosis was detected via flow cytometry. The results indicated that, after incubation for $24 \mathrm{~h}$, the total apoptotic rate of the cells treated with $0 \mathrm{mg} / \mathrm{ml}$ sericin was $16.66 \pm 1.95 \%$, with early and late apoptotic rates of $4.51 \pm 0.84$ and $12.15 \pm 1.25 \%$, respectively. However, the total apoptotic rate of the cells treated with $8 \mathrm{mg} / \mathrm{ml}$ sericin was increased to $41.93 \pm 1.13 \%$ in MDA-MB-468 cells $(\mathrm{F}=233.551 ; \mathrm{P}<0.001)$, with early and late apoptotic rates of up to $12.76 \pm 0.49$ and $29.17 \pm 0.81 \%$, respectively (Fig. 3A and B). In addition, the effects of sericin on the expression levels of apoptosis-related proteins were investigated. The protein expression levels of $\mathrm{Bax}(\mathrm{F}=222.130$; $\mathrm{P}<0.001)$ and Cyto-C protein $(\mathrm{F}=55.296 ; \mathrm{P}<0.001)$ were upregulated, while $\mathrm{Bcl}-2$ protein expression $(\mathrm{F}=92.422 ; \mathrm{P}<0.001)$ was significantly downregulated after treatment with sericin, in a dose-dependent manner (Fig. 3C and D). These results suggested that sericin could induce the cellular apoptosis in MDA-MB-468 cells.

PI3K/Akt pathway is dysregulated in TNBC. To screen the pathways associated with tumorigenesis and progression of TNBC, the normal mammary tissue dataset GSE112825 and TNBC tissue dataset GSE76124 were analyzed. These two datasets 

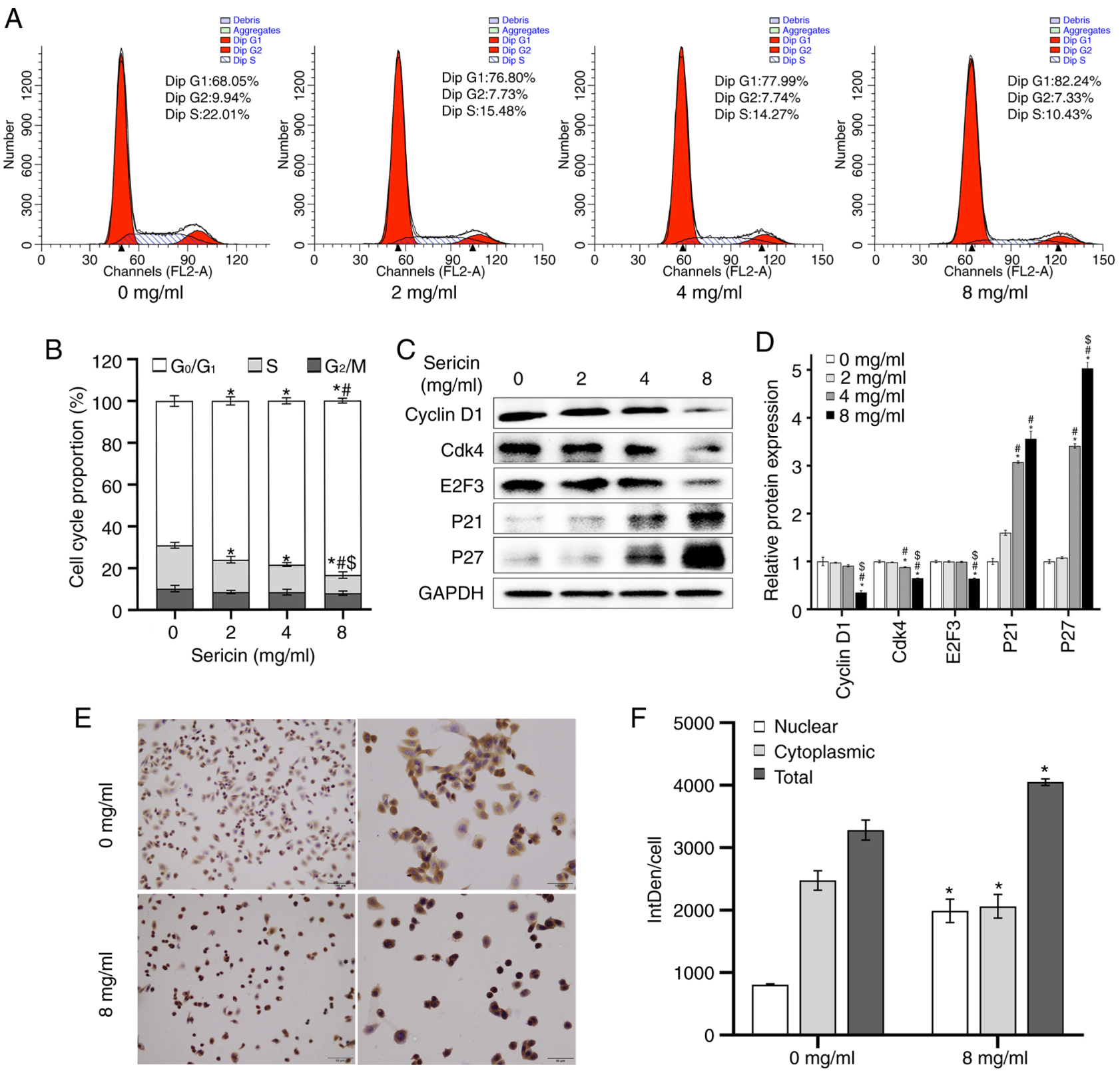

Figure 2. Sericin induces cell cycle arrest at the $\mathrm{G}_{0} / \mathrm{G}_{1}$ phase in MDA-MB-468 cells. (A) MDA-MB-468 cells were treated with sericin, at $0,2,4$ and $8 \mathrm{mg} / \mathrm{ml}$ for $24 \mathrm{~h}$, and the cell cycle was assessed via flow cytometry. (B) Quantitation of flow cytometry assays. (C) Expression levels of $\mathrm{G}_{1}$ phase-related proteins in MDA-MB-468 cells were detected via western blot analysis. (D) Semi-quantitative analysis of the results from the western blot analysis. (E) Immunocytochemistry staining of P21. Magnification, $x 100$ or $x 400$. Cells were treated with $8 \mathrm{mg} / \mathrm{ml}$ sericin and were analyzed in comparison with the $0 \mathrm{mg} / \mathrm{ml}$ group. (F) Quantitative analysis of the immunocytochemistry staining. ${ }^{*} \mathrm{P}<0.05 \mathrm{vs} .0 \mathrm{mg} / \mathrm{ml}$ group; ${ }^{*} \mathrm{P}<0.05 \mathrm{vs} .2 \mathrm{mg} / \mathrm{ml}$ group; ${ }^{\$} \mathrm{P}<0.05 \mathrm{vs} .4 \mathrm{mg} / \mathrm{ml}$ group. E2F3, E2F transcription factor 3.

consisted of 109 normal mammary tissue samples and 198 TNBC tissue samples. Based on the $\mid \log _{2}$ (fold-change) $\mid>2$ and $\mathrm{P}<0.05$, a total of 1,091 differentially expressed genes were identified, including 764 upregulated and 327 downregulated genes. As presented in Fig. 4A, the top 100 genes were selected based on the significant changes. Moreover, the GO and KEGG pathway analyses were applied to predict the differentially expressed genes (Fig. 4B). The GO analysis of the altered genes revealed that the top two enriched BPs were 'aromatic compound biosynthetic process' and 'heterocycle biosynthetic process'. 'Extracellular region' and 'carbohydrate derivative binding' were the top-ranked CC and MF, respectively. The KEGG analysis indicated that the most significant pathways included 'pathways in cancer' and the 'PI3K/Akt signaling pathway' (Fig. 4B). Validation performed in GSEA demonstrated similar results to the KEGG analysis, suggesting that the PI3K/Akt signaling pathway was significantly altered in TNBC (Fig. 4C). Then, the 30 genes enriched in this pathway were extracted, the expression levels of which in normal mammary tissues and TNBC tissues were visualized (Fig. 4D).

It was then investigated whether the aforementioned genes were associated with the overall survival of patients with breast cancer, which was predicted using the Kaplan-Meier survival curves and log-rank test. Among the evaluated genes, 27 genes, such as HSP90AB1, FGF7, FGFR3 and KIT, demonstrated a significant association with the overall 

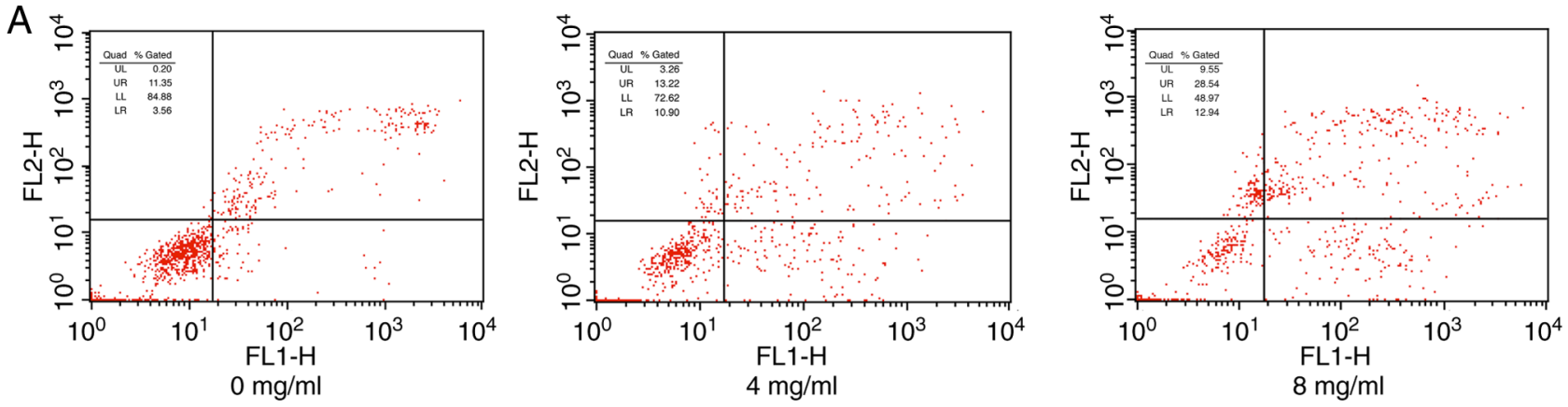

B
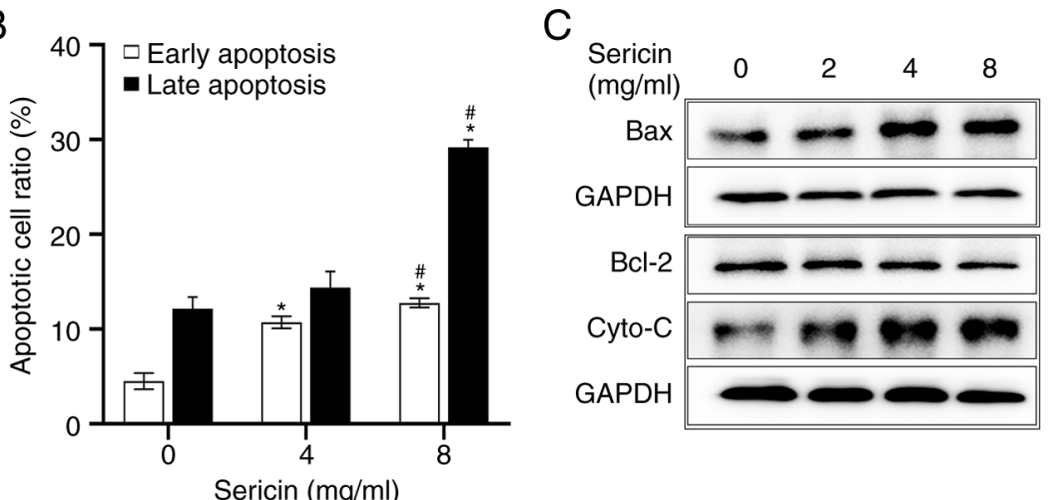

$\mathrm{D}$

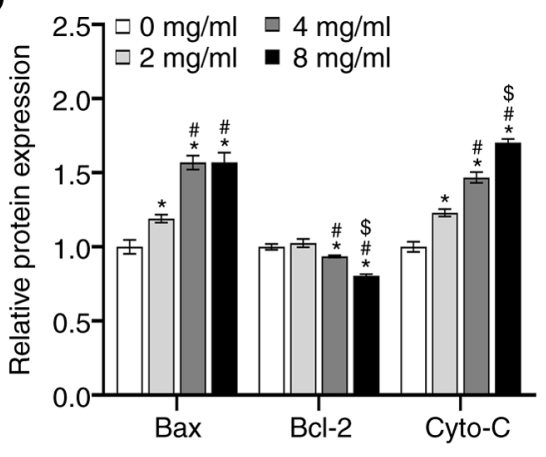

Figure 3. Sericin promotes MDA-MB-468 cellular apoptosis. (A) Cells were treated with sericin at indicated concentrations, and the cellular apoptosis was detected with flow cytometry. (B) Quantitative analysis of the results from flow cytometry. (C) Expression levels of apoptosis-related proteins (Bax, Bcl-2 and Cyto-C) were determined via western blot analysis. (D) Semi-quantitative analysis of the results from the western blot analysis. ${ }^{*} \mathrm{P}<0.05 \mathrm{vs} .0 \mathrm{mg} / \mathrm{ml}$ group; ${ }^{\text {" }} \mathrm{P}<0.05$ vs. $2 \mathrm{mg} / \mathrm{ml}$ group; ${ }^{\text {S }} \mathrm{P}<0.05$ vs. $4 \mathrm{mg} / \mathrm{ml}$ group. Cyto-C, Cytochrome $c$.

survival (Fig. 5). These results indicated that the dysregulated $\mathrm{PI} 3 \mathrm{~K} / \mathrm{Akt}$ pathway serves a major role in the tumorigenesis and progression of TNBC.

Sericin suppresses the PI3K/Akt signaling pathway. Differentially expressed genes between normal mammary tissues and TNBC tissues involved in the PI3K/Akt signaling pathway were screened based on the KEGG analysis (Fig. 6). To verify whether the effects of sericin on TNBC were associated with the PI3K/Akt pathway, the protein expression levels of PI3K, Akt and other critical genes enriched in PI3K/Akt pathway were examined. The present results suggested that, after treatment of sericin, the protein expression levels of PI3K ( F=35.494; $\mathrm{P}<0.001)$, Akt $(\mathrm{F}=11.175 ; \mathrm{P}=0.003)$, $\mathrm{p}-\mathrm{Akt}$ $(\mathrm{F}=260.046 ; \mathrm{P}<0.001), \mathrm{HSP} 90(\mathrm{~F}=398.631 ; \mathrm{P}<0.001)$ and $\mathrm{Bcl}-2$ $(\mathrm{F}=92.422 ; \mathrm{P}<0.001)$ were significantly decreased compared with the cells treated with $0 \mathrm{mg} / \mathrm{ml}$ sericin (Fig. 7A and B). Additionally, the ratio of $\mathrm{p}$-Akt to total Akt was calculated and sericin treatment significantly decreased the $\mathrm{p}-\mathrm{Akt} / \mathrm{Akt}$ ratio $(\mathrm{F}=47.365 ; \mathrm{P}<0.001)$.

Subsequently, the AKT agonist SC79 (10 $\mu \mathrm{M}$; HY-18749; MedChemExpress) was used to treat the cells for $2 \mathrm{~h}$, following sericin treatment. As demonstrated by the MTT assay, the viability of the MDA-MB-468 cells treated with $8 \mathrm{mg} / \mathrm{ml}$ sericin in combination with SC79 was significantly higher compared with that of the cells treated with $8 \mathrm{mg} / \mathrm{ml}$ sericin alone $(\mathrm{P}<0.001$; Fig. 7C). Moreover, the viability of these two groups was significantly lower compared with that of the cells treated with $0 \mathrm{mg} / \mathrm{ml}$ sericin $(\mathrm{P}<0.001)$. A decrease in sericin $(8 \mathrm{mg} / \mathrm{ml})$-mediated growth inhibition was also identified in
MDA-MB-468 cells after co-treatment with SC79, according to the colony formation assay $(\mathrm{P}=0.002$; Fig. $7 \mathrm{D}$ and $\mathrm{E})$. Similar results were observed for the expression levels of Ki67 as examined via immunocytochemistry staining $(\mathrm{P}=0.011$; Fig. 7F and G). These findings suggested that SC79 partially restored the sericin-induced suppression of MDA-MB-468 cell viability. Collectively, these results indicated that sericin modulated MDA-MB-468 cell proliferation by suppressing the PI3K/Akt signaling pathway.

\section{Discussion}

Sericin is a major constituent of silk, produced by silkworms and is widely used in researches of biology and medicine (27). An increasing number of studies have reported that sericin is a potent natural antioxidant, which has been shown to exert anticoagulation activity, anti-inflammatory activity, low immunogenicity and excellent biocompatibility $(11,28,29)$. Despite these findings, little is known regarding the activity and underlying mechanisms of sericin in tumor pathogenesis. The present results demonstrated that sericin significantly suppressed TNBC cell proliferation, induced $G_{0} / G_{1}$ cell cycle arrest and promoted cell apoptosis by inhibiting the PI3K/Akt signaling pathway.

Cancer types are characterized by their abilities to sustain proliferation. Cancer cells, by controlling the proliferating and cell cycle signals, become masters of their own destinies (30). The present results suggested that the TNBC cell lines MDA-MB-468 and MDA-MB-453, but not the non-TNBC cell line MCF-7, were highly sensitive to the 


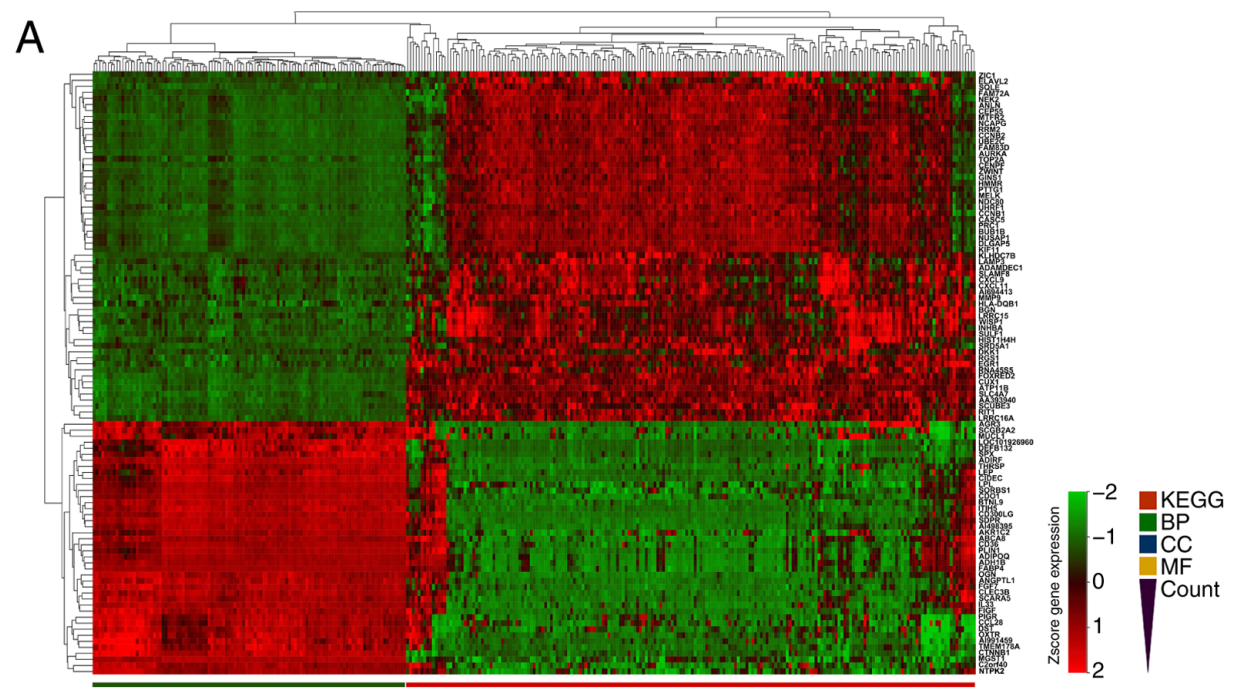

Normal $n=109$

TNBC $n=198$

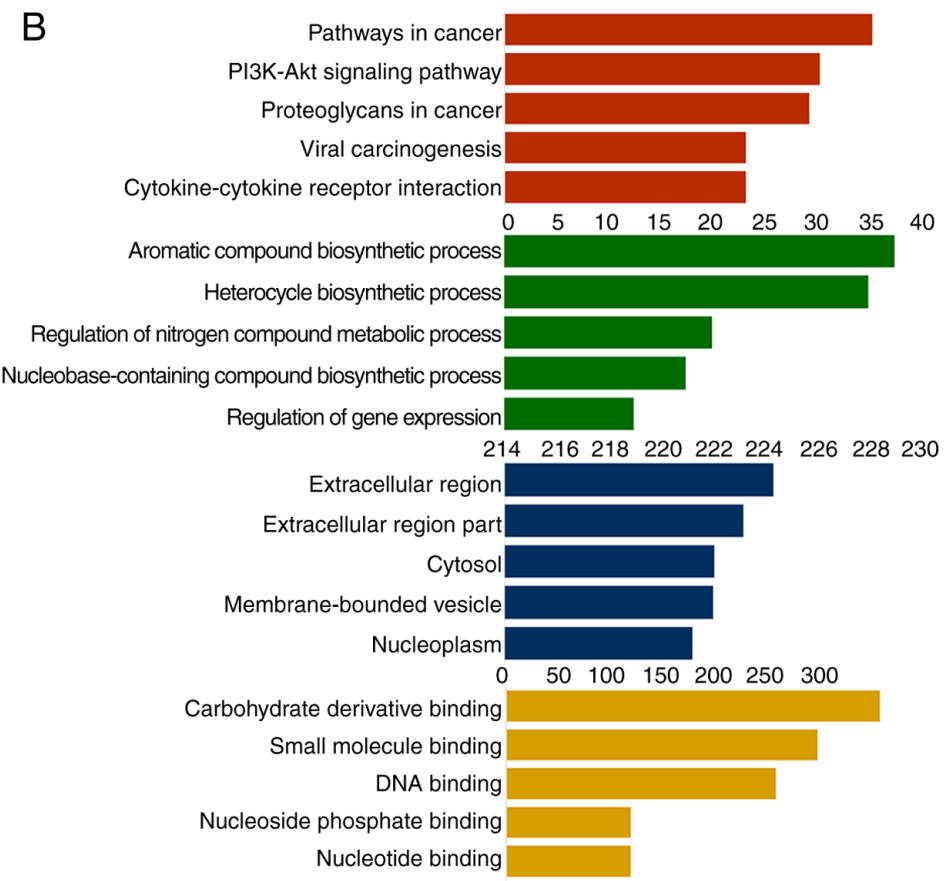

\section{C}

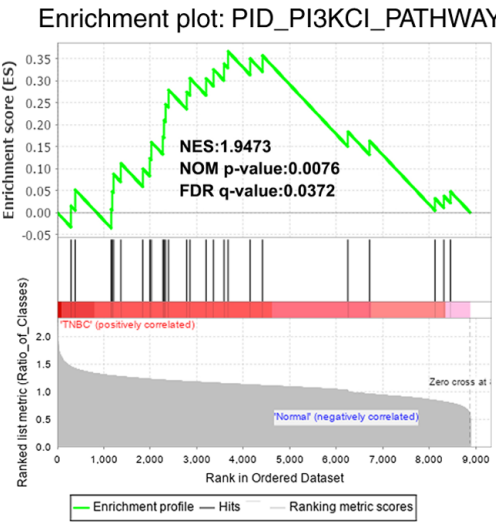

120122124126128130132134136138140

$\mathrm{D}$

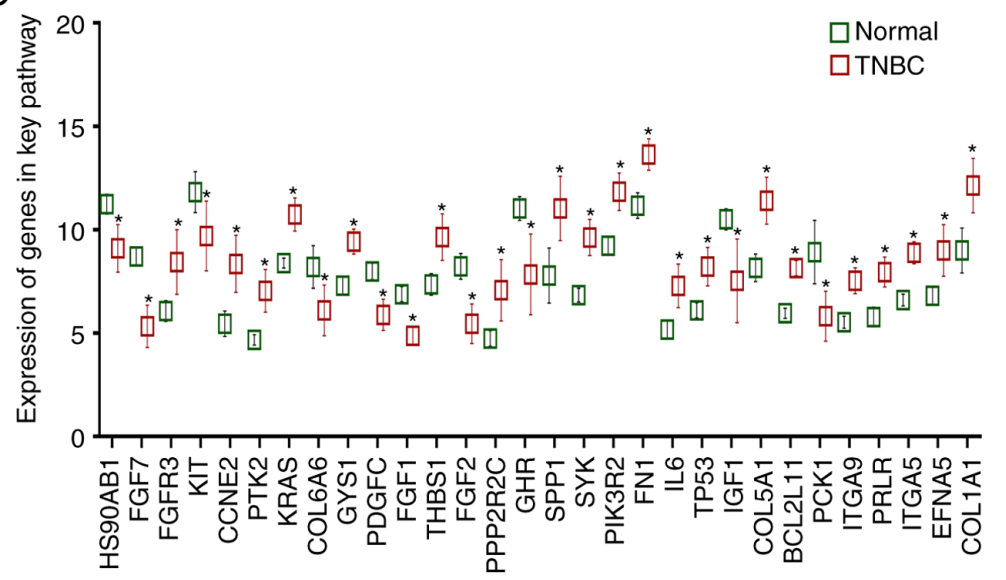

Figure 4. PI3K/Akt pathway is dysregulated in TNBC, based on bioinformatics analysis. (A) Heatmap of the top 100 differentially expressed genes. (B) Gene Ontology functional and Kyoto Encyclopedia of Genes and Genomes pathway enrichment analyses of differentially expressed genes. (C) Gene set enrichment analysis comparing the normal mammary tissue dataset and TNBC tissue dataset. (D) Visualization of the expression levels of the 30 differentially expressed genes in PI3K/Akt pathways. "P<0.05 vs. normal mammary tissue dataset. TNBC, triple negative breast cancer; FDR, false discovery rate; NES, normalized enrichment score; NOM, nominal; BP, biological process; CC, cellular component; MF, molecular function. 

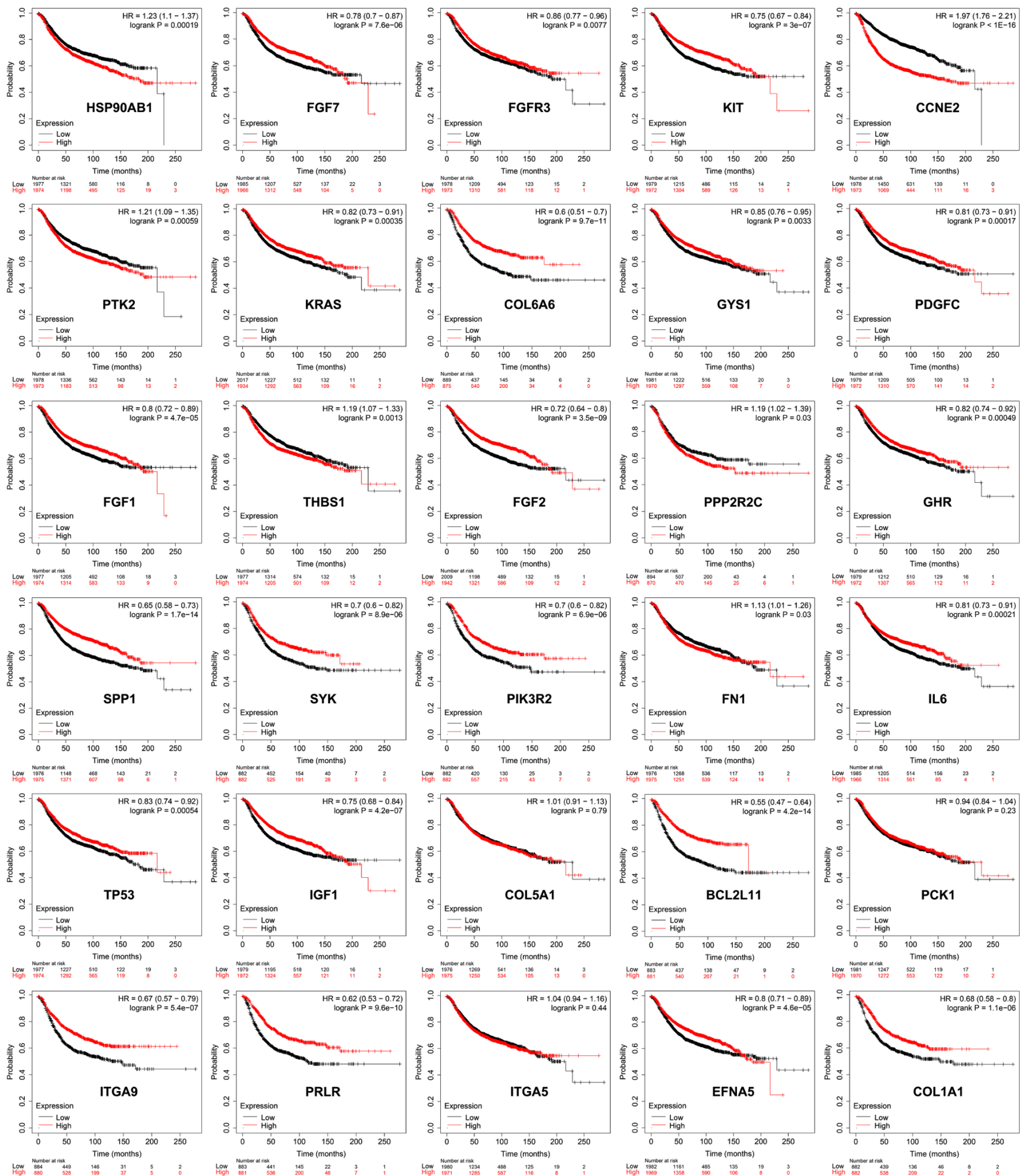

Figure 5. Kaplan-Meier overall survival curves of the 30 differentially expressed genes enriched in PI3K/Akt pathways.

exposure of sericin, which exhibited the growth inhibiting function. It has been proposed that the proliferation of MCF-7 cells could be suppressed by sericin (21). In total, three types of alkali-degraded sericin were selected in a study by Kumar and Mandal; however, only the Antheraea assamensis-derived sericin exhibited anti-proliferative abilities in MCF-7 cells. This may be due to fact that the properties of sericin are closely correlated with the extraction methods and places of origin (21). Along with the aforementioned studies that have examined the effects of sericin on TNBC cell viability, Guo et al (15) revealed that the sericin treatment significantly inhibited the human gastric cancer MKN45 cell proliferation and induced cell cycle arrest both in vitro and in nude mice. Moreover, the present results suggested that sericin exhibited 
PISK-AKT SIGNALING PATHWAY

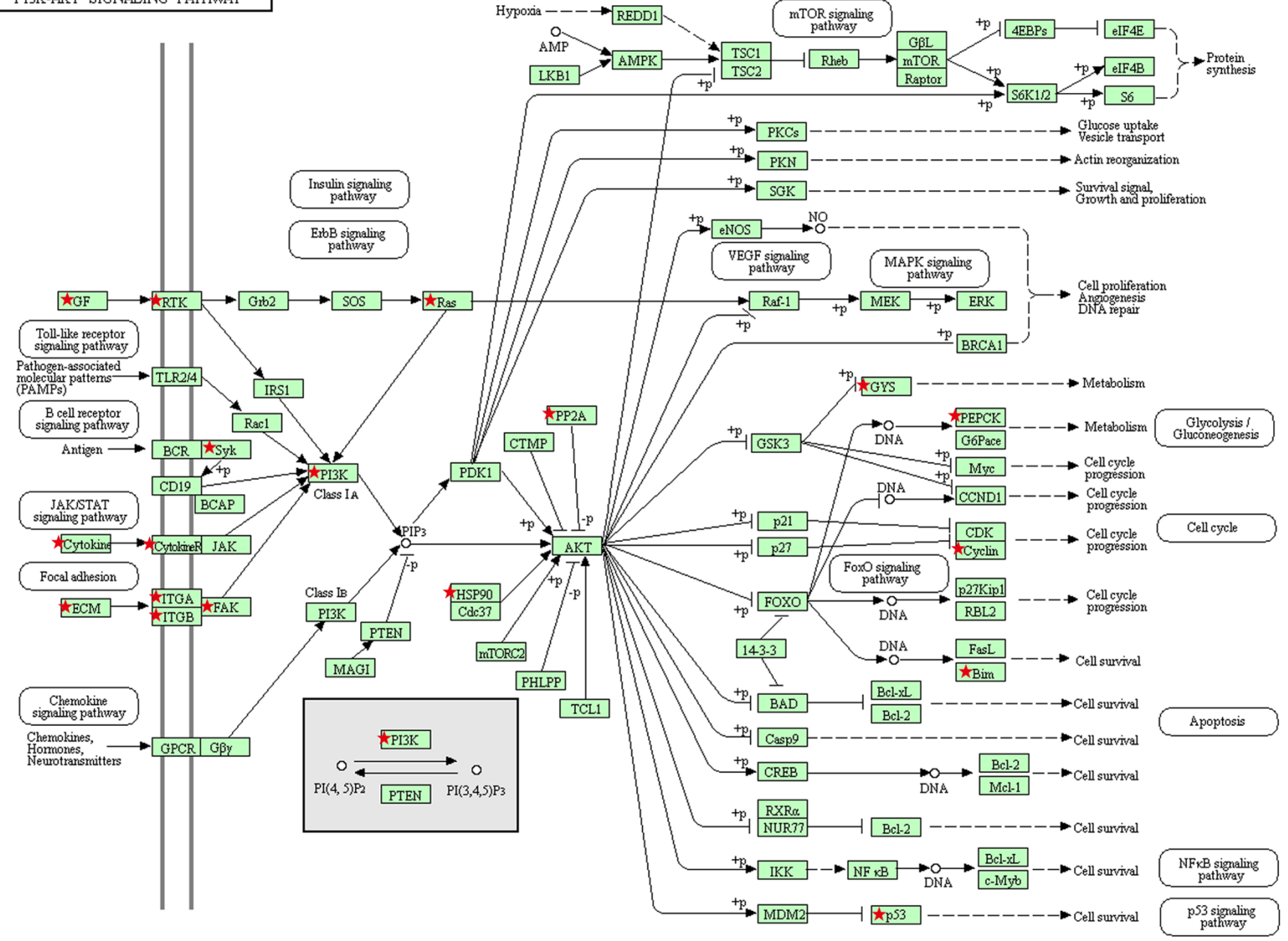

O4151 10:3/19
(c) Kanelisa Laboratories Copyright permission is granted by Kanehisa Laboratories

Figure 6. Differentially expressed genes between normal mammary tissues and triple negative breast cancer tissues involved in PI3K/Akt signaling pathway based on the Kyoto Encyclopedia of Genes and Genomes analysis. Copyright permission was granted by Kanehisa Laboratories.

specific antitumor properties in TNBC cell lines, with no toxicity to the normal breast epithelial cell line MCF-10A, which was consistent with the findings from Kumar and Mandal (21), which indicated that sericin could not disrupt the cellular membrane integrity, and cause little toxicity in non-tumorigenic epithelial (MCF-10) cells and keratinocyte (HaCaT) cells. Therefore, the role of sericin on TNBC cells warrants further investigation.

The present results demonstrated that sericin effectively induced MDA-MB-468 cell cycle arrest at the $\mathrm{G}_{0} / \mathrm{G}_{1}$ phase. The cell cycle is regulated at two transition points, known as the $\mathrm{G}_{1} / \mathrm{S}$ and $\mathrm{G}_{2} / \mathrm{M}$ points (31). Cyclin D1 can form a complex with Cdk4 to control the $\mathrm{G}_{1} / \mathrm{S}$ biological processes (32). E2F3 is a transcriptional activator from the E2F family, which positively regulates the transition from the $\mathrm{G}_{1}$ to $\mathrm{S}$ phase (33). Moreover, P21 and P27, as Cip/Kip family members, share a conserved $\mathrm{N}$-terminal domain that mediates the binding to Cyclins and Cdks, thereby affecting and regulating the cell cycle (34). The present results indicated that the expression levels of P21 and P27 were elevated after sericin treatment. Additionally, P21, a typical cell cycle inhibitor, serves diverse roles in tumor cells, depending on its intracellular localization. In the nucleus, P21 acts as a potent inhibitor of cellular proliferation, which abolishes the tumor-suppressive role, but this factor promotes tumor growth when in the cytosol of cancer cells $(35,36)$. Sericin effectively led to a marked accumulation of P21 in the nucleus. Collectively, it was suggested that sericin could inhibit the TNBC cell proliferation and induce the cell cycle arrest.

Evading apoptosis is one of the hallmarks of cancer cells. Cells may achieve this function by increasing the expression levels of antiapoptotic regulators (such as Bcl-2), and/or downregulating the pro-apoptotic factors, such as Bax and Bak (30). The present results demonstrated that sericin promoted the apoptotic process in the MDA-MB-468 cells. Sericin increased the number of early and late apoptotic cells, as well as upregulated Bax and downregulated Bcl-2 expression levels. In line with the current findings, Kaewkorn et al (16) reported that sericin promoted the apoptosis of human colon cancer SW480 cells, with increased caspase-3 activity and decreased Bcl-2 expression. Additionally, Kumar and Mandal (21) revealed that the silk sericin can lead to the apoptosis of tongue carcinoma SAS cells, by regulating the expression levels of Cyto-C and Caspase-3. Mitochondrial membrane permeability is increased, and Cyto-C is released from mitochondria to cytoplasm, following the exposure to sericin (21). The present results demonstrated that the protein expression levels of Cyto-C were 

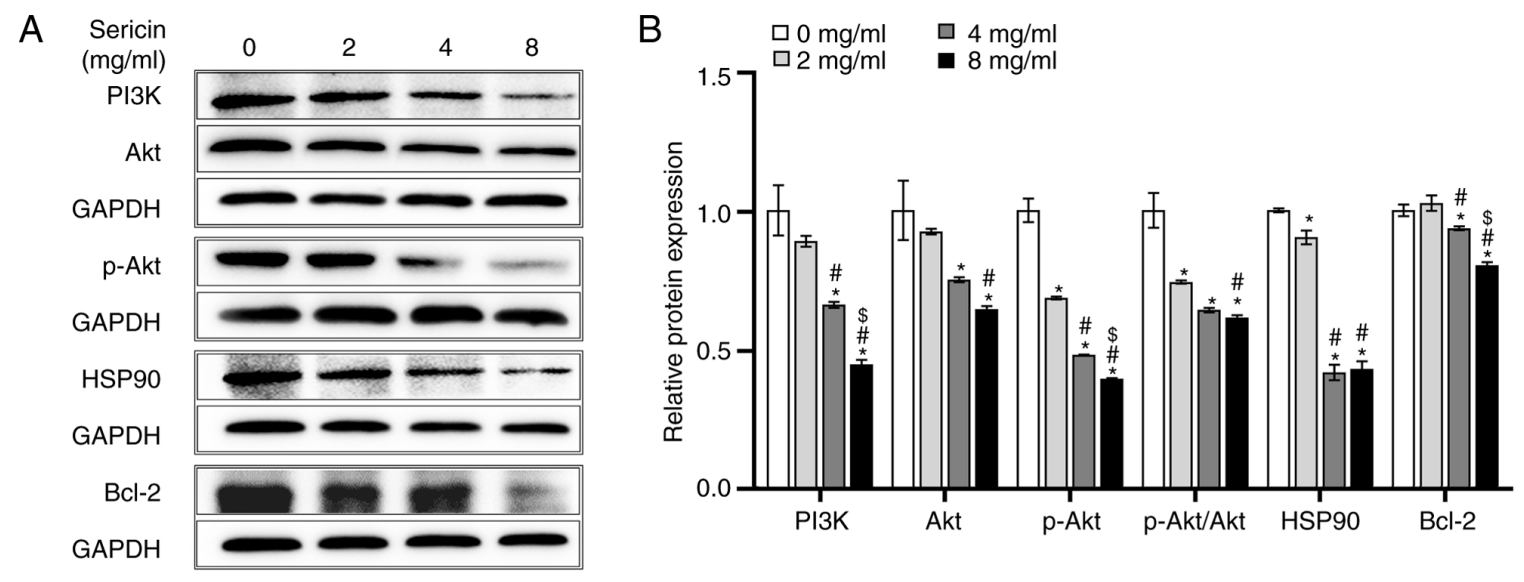
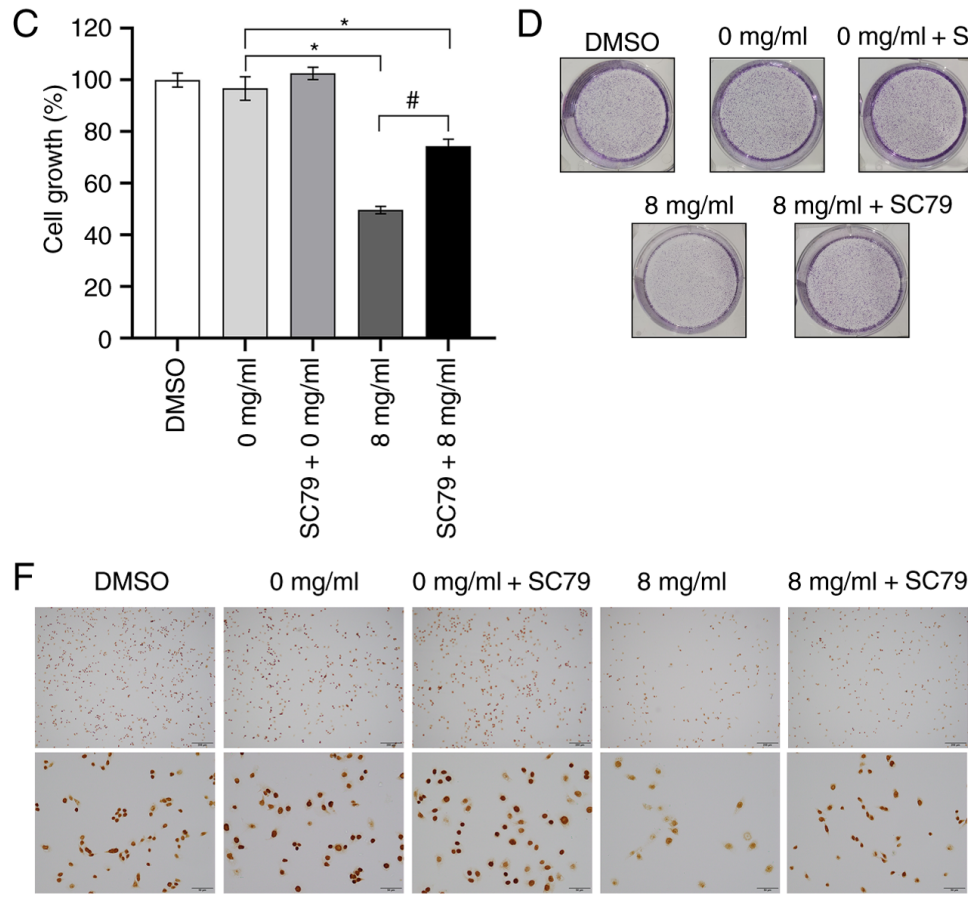

D
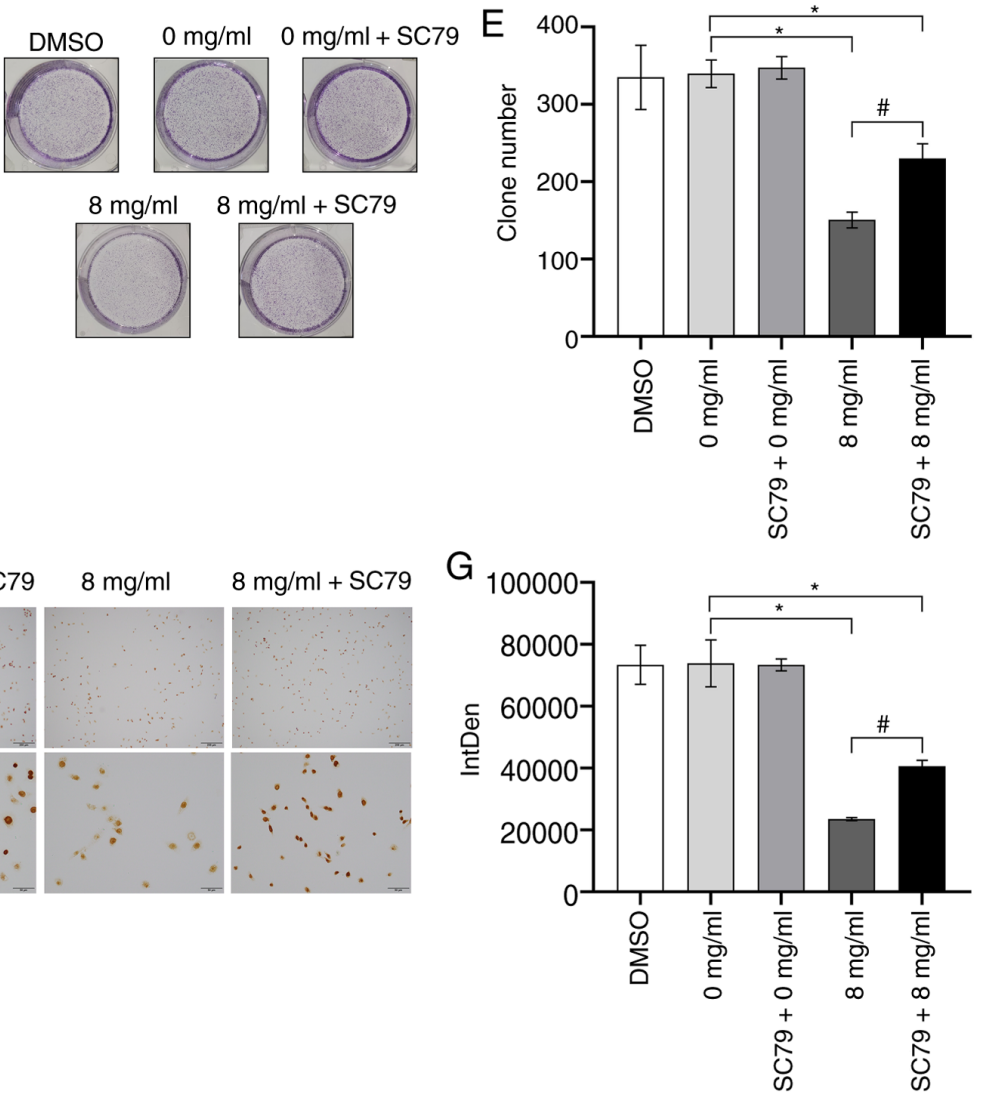

Figure 7. Sericin suppresses the PI3K/Akt signaling pathway. (A) PI3K/Akt pathway proteins were analyzed via western blot analysis. (B) Semi-quantitative analysis of the results from the western blot analysis. ${ }^{*} \mathrm{P}<0.05$ vs. $0 \mathrm{mg} / \mathrm{ml}$ group; ${ }^{\#} \mathrm{P}<0.05 \mathrm{vs} .2 \mathrm{mg} / \mathrm{ml}$ group; ${ }^{~} \mathrm{P}<0.05 \mathrm{vs}$. $4 \mathrm{mg} / \mathrm{ml}$ group. MDA-MB-468 cells were treated with 0 or $8 \mathrm{mg} / \mathrm{ml}$ sericin for $24 \mathrm{~h}$ and then exposed to treatment of $10 \mu \mathrm{M} \mathrm{SC79}$ for $2 \mathrm{~h}$. Cell proliferation was detected using a (C) MTT assay, (D) colony formation assay and (F) immunocytochemistry staining. Magnification, x100 or x400. (E) Quantitative analysis of the clone numbers. (G) Quantitative analysis of the immunocytochemistry staining. " $\mathrm{P}<0.05$ vs. $0 \mathrm{mg} / \mathrm{ml}$ group; ${ }^{\#} \mathrm{P}<0.05 \mathrm{vs} .8 \mathrm{mg} / \mathrm{ml}$ group. HSP 90 , Heat shock protein 90 ; p-, phosphorylated.

significantly elevated, suggesting that the pro-apoptotic effects of sericin could be achieved by activating the mitochondrial signal pathway. All these findings indicate the pro-apoptotic properties of sericin in the MDA-MB-468 cells.

In the current study, the mechanism of sericin-induced proliferation inhibition of TNBC cells was also investigated. TNBC is a subtype of breast cancer with an aggressive phenotype, which leads to very poor prognosis for metastatic diseases, and has limited treatment options (37). Several researchers have studied the key sites, hub genes and/or specific prognostic biomarkers of TNBC, comparing them with non-TNBC, based on bioinformatic analysis $(38,39)$. den Hollander et al (40) proposed that protein tyrosine phosphatase 4A3 could serve as an independent prognostic indicator in TNBC, compared with ER-positive breast cancer, according to the Affymetrix microarray analysis. However, few studies have been reported concerning the bioinformatics examination of key pathways between TNBC tissues and normal mammary tissues.

In the present study, two gene expression profiles, including the TNBC and normal mammary tissue samples, were obtained from the GEO database. Differentially expressed genes were 
screened out, and the pathway analysis identified that the PI3K/Akt signaling pathway was most significantly affected in TNBC. Based on these findings, the effects of sericin on the PI3K/Akt signaling pathway were investigated. In addition, other related proteins in the PI3K/Akt pathway were detected, including HSP90 and Bcl-2. It was found that HSP90 and Bcl-2 were associated with the overall survival of patients with breast cancer. HSP90 is a molecular chaperone that supports the stability of the client proteins, including the Akt and FKBP prolyl isomerase 4, which has been considered to be responsible for multiple malignant tumors, such as breast cancer and prostate cancer (41-43). The present results indicated that when sericin exerted its antitumor effects, the PI3K/Akt signaling pathway was inhibited and HSP90 activity was suppressed. These findings suggested that the potential antitumor role of sericin may be achieved, at least partially, by suppressing the PI3K/Akt pathway in TNBC.

In conclusion, the present study demonstrated that sericin, a natural water-soluble protein with excellent drug-like characteristics, was able to suppress cell proliferation, induce $\mathrm{G}_{0} / \mathrm{G}_{1}$ cell cycle arrest and promote cell apoptosis in TNBC MDA-MB-468 cells. It was suggested that sericin may exert its biological functions by inhibiting the PI3K/Akt signaling pathway. However, the lack of multiple TNBC cell lines to assess these findings was a limitation of the present study, which remains to be examined in the future. Collectively, the present findings may provide evidence and inspire novel ideas for the investigation of TNBC.

\section{Acknowledgements}

Not applicable.

\section{Funding}

The research was funded by National Natural Science Foundation of China (grant nos. 81441133 and 81703001), Natural Science Foundation of Hebei Province (grant no. H2013406115) and Chengde Medical University Scientific Research Major Projects (grant no. KY2020005).

\section{Availability of data and materials}

All data generated or analyzed during this present study are included in this article. The GSE112825 and GSE76124 datasets analyzed for this study can be found in GEO database (https://www.ncbi.nlm.nih.gov/geo/).

\section{Authors' contributions}

LN performed most of the experiments. SY and LL analyzed the experimental results. XZ and XL performed experiments and acquired data. LS and MW participated in the western blot analysis. LC helped with bioinformatics analysis. ZC and YQ designed and directed the study. All authors read and approved the final manuscript.

\section{Ethics approval and consent to participate}

Not applicable.

\section{Patient consent for publication}

Not applicable.

\section{Competing interests}

The authors declare that they have no competing interests.

\section{References}

1. Kumar P and Aggarwal R: An overview of triple-negative breast cancer. Arch Gynecol Obstet 293: 247-269, 2016.

2. Kim A, Jang MH, Lee SJ and Bae YK: Mutations of the epidermal growth factor receptor gene in triple-negative breast cancer. J Breast Cancer 20: 150-159, 2017.

3. Zhao Z, Li L, Du P, Ma L, Zhang W, Zheng L, Lan B, Zhang B, Ma F, Xu B, et al: Transcriptional downregulation of miR-4306 serves as a new therapeutic target for triple negative breast cancer. Theranostics 9: 1401-1416, 2019.

4. Abramson VG and Mayer IA: Molecular heterogeneity of triple negative breast cancer. Curr Breast Cancer Rep 6: 154-158, 2014.

5. Abramson VG, Lehmann BD, Ballinger TJ and Pietenpol JA: Subtyping of triple-negative breast cancer: Implications for therapy. Cancer 121: 8-16, 2015.

6. Pandey MK, Gupta SC, Nabavizadeh A and Aggarwal BB: Regulation of cell signaling pathways by dietary agents for cancer prevention and treatment. Semin Cancer Biol 46: 158-181, 2017.

7. Cao TT and Zhang YQ: Processing and characterization of silk sericin from bombyx mori and its application in biomaterials and biomedicines. Mater Sci Eng C Mater Biol Appl 61: 940-952, 2016.

8. Zhang YQ, Tao ML, Shen WD, Zhou YZ, Ding Y, Ma Y and Zhou WL: Immobilization of L-asparaginase on the microparticles of the natural silk sericin protein and its characters. Biomaterials 25: 3751-3759, 2004.

9. Yasmin C, Otoi T, Setiadi MA and Karja NW: Maturation and fertilisation of sheep oocytes cultured in serum-free medium containing silk protein sericin. Acta Vet Hung 63: 110-117, 2015.

10. Okazaki Y, Kakehi S, Xu Y, Tsujimoto K, Sasaki M, Ogawa H and Kato N: Consumption of sericin reduces serum lipids, ameliorates glucose tolerance and elevates serum adiponectin in rats fed a high-fat diet. Biosci Biotechnol Biochem 74: 1534-1538, 2010.

11. Suktham K, Koobkokkruad T, Wutikhun T and Surassmo S: Efficiency of resveratrol-loaded sericin nanoparticles: Promising bionanocarriers for drug delivery. Int J Pharm 537: 48-56, 2018.

12. Song CJ, Fu XM, Li J and Chen ZH: Effects of sericine on TGF-beta1/Smad3 signal pathway of diabetic mephropathy rats kidney. Zhongguo Ying Yong Sheng Li Xue Za Zhi 27: 102-105, 2011 (In Chinese).

13. Chen Z, He Y, Song C, Dong Z, Su Z and Xue J: Sericin can reduce hippocampal neuronal apoptosis by activating the Akt signal transduction pathway in a rat model of diabetes mellitus. Neural Regen Res 7: 197-201, 2012.

14. Song CJ, Yang ZJ, Tang QF and Chen ZH: Effects of sericin on the testicular growth hormone/insulin-like growth factor-1 axis in a rat model of type 2 diabetes. Int J Clin Exp Med 8: 10411-10419, 2015

15. Guo WH, Chen ZY, Chen H, Lin T, Zhao ML, Liu H, Yu J, $\mathrm{Hu}$ YF and Li GX: Sericin regulates proliferation of human gastric cancer MKN45 cells through autophagic pathway. Nan Fang Yi Ke Da Xue Xue Bao 38: 148-154, 2018 (In Chinese).

16. Kaewkorn W, Limpeanchob N, Tiyaboonchai W, Pongcharoen S and Sutheerawattananonda M: Effects of silk sericin on the proliferation and apoptosis of colon cancer cells. Biol Res 45: 45-50, 2012.

17. Sasaki M, Kato N, Watanabe H and Yamada H: Silk protein, sericin, suppresses colon carcinogenesis induced by 1,2-dimethylhydrazine in mice. Oncol Rep 7: 1049-1052, 2000.

18. Zhaorigetu S, Sasaki M, Watanabe H and Kato N: Supplemental silk protein, sericin, suppresses colon tumorigenesis in 1,2-dimethylhydrazine-treated mice by reducing oxidative stress and cell proliferation. Biosci Biotechnol Biochem 65: 2181-2186, 2001.

19. Zhaorigetu S, Yanaka N, Sasaki M, Watanabe H and Kato N: Inhibitory effects of silk protein, sericin on UVB-induced acute damage and tumor promotion by reducing oxidative stress in the skin of hairless mouse. J Photochem Photobiol B 71: 11-17, 2003. 
20. Zhaorigetu S, Yanaka N, Sasaki M, Watanabe H and Kato N: Silk protein, sericin, suppresses DMBA-TPA-induced mouse skin tumorigenesis by reducing oxidative stress, inflammatory responses and endogenous tumor promoter TNF-alpha. Oncol Rep 10: 537-543, 2003.

21. Kumar JP and Mandal BB: Silk sericin induced pro-oxidative stress leads to apoptosis in human cancer cells. Food Chem Toxicol 123: 275-287, 2019 .

22. Santucci-Pereira J, Zeleniuch-Jacquotte A, Afanasyeva Y, Zhong H, Slifker M, Peri S, Ross EA, López de Cicco R, Zhai Y, Nguyen T, et al: Genomic signature of parity in the breast of premenopausal women. Breast Cancer Res 21: 46, 2019.

23. Burstein MD, Tsimelzon A, Poage GM, Covington KR, Contreras A, Fuqua SA, Savage MI, Osborne CK, Hilsenbeck SG, Chang JC, et al: Comprehensive genomic analysis identifies novel subtypes and targets of triple-negative breast cancer. Clin Cancer Res 21: 1688-1698, 2015.

24. Edgar R, Domrachev M and Lash AE: Gene expression omnibus: NCBI gene expression and hybridization array data repository. Nucleic Acids Res 30: 207-210, 2002.

25. Kanehisa M: Toward understanding the origin and evolution of cellular organisms. Protein Sci 28: 1947-1951, 2019.

26. Nagy Á, Lánczky A, Menyhárt O and Győrffy B: Validation of miRNA prognostic power in hepatocellular carcinoma using expression data of independent datasets. Sci Rep 8: 9227, 2018.

27. Kunz RI, Brancalhão RM, Ribeiro LF and Natali MR: Silkworm sericin: Properties and biomedical applications. Biomed Res Int 2016: 8175701, 2016

28. Jena K, Pandey JP, Kumari R, Sinha AK, Gupta VP and Singh GP: Tasar silk fiber waste sericin: New source for anti-elastase, anti-tyrosinase and anti-oxidant compounds. Int J Biol Macromol 114: 1102-1108, 2018.

29. Aramwit P, Kanokpanont S, De-Eknamkul W and Srichana T: Monitoring of inflammatory mediators induced by silk sericin. J Biosci Bioeng 107: 556-561, 2009.

30. Hanahan D and Weinberg RA: Hallmarks of cancer: The next generation. Cell 144: 646-674, 2011

31. Purdy A, Uyetake L, Cordeiro MG and Su TT: Regulation of mitosis in response to damaged or incompletely replicated DNA require different levels of Grapes (Drosophila Chk1). J Cell Sci 118: 3305-3315, 2005.

32. John RR, Malathi N, Ravindran C and Anandan S: Mini review: Multifaceted role played by cyclin D1 in tumor behavior. Indian J Dent Res 28: 187-192, 2017

33. Lim S and Kaldis P: Cdks, cyclins and CKIs: Roles beyond cell cycle regulation. Development 140: 3079-3093, 2013.
34. Besson A, Dowdy SF and Roberts JM: CDK inhibitors: Cell cycle regulators and beyond. Dev Cell 14: 159-169, 2008.

35. Roninson IB: Oncogenic functions of tumour suppressor p21(Waf1/Cip1/Sdi1): Association with cell senescence and tumour-promoting activities of stromal fibroblasts. Cancer Lett 179: 1-14, 2002.

36. Suzuki A, Tsutomi Y, Miura M and Akahane K: Caspase 3 inactivation to suppress Fas-mediated apoptosis: Identification of binding domain with $\mathrm{p} 21$ and ILP and inactivation machinery by p21. Oncogene 18: 1239-1244, 1999.

37. Zagorac I, Fernandez-Gaitero S, Penning R, Post H, Bueno MJ, Mouron S, Manso L, Morente MM, Alonso S, Serra V, et al: In vivo phosphoproteomics reveals kinase activity profiles that predict treatment outcome in triple-negative breast cancer. Nat Commun 9: 3501, 2018.

38. Zhang C, Han Y, Huang H, Min L, Qu L and Shou C: Integrated analysis of expression profiling data identifies three genes in correlation with poor prognosis of triple-negative breast cancer. Int J Oncol 44: 2025-2033, 2014.

39. Bao C, Lu Y, Chen J, Chen D, Lou W, Ding B, Xu L and Fan W: Exploring specific prognostic biomarkers in triple-negative breast cancer. Cell Death Dis 10: 807, 2019.

40. den Hollander P, Rawls K, Tsimelzon A, Shepherd J, Mazumdar A, Hill J, Fuqua SA, Chang JC, Osborne CK, Hilsenbeck SG, et al: Phosphatase PTP4A3 promotes triple-negative breast cancer growth and predicts poor patient survival. Cancer Res 76: 1942-1953, 2016.

41. Neckers L and Workman P: Hsp90 molecular chaperone inhibitors: Are we there yet? Clin Cancer Res 18: 64-76, 2012.

42. He Y, Peng S, Wang J, Chen H, Cong X, Chen A, Hu M, Qin M Wu H, Gao S, et al: Ailanthone targets p23 to overcome MDV3100 resistance in castration-resistant prostate cancer. Nat Commun 7: 13122, 2016.

43. Mangé A, Coyaud E, Desmetz C, Laurent E, Béganton B Coopman P, Raught B and Solassol J: FKBP4 connects mTORC2 and PI3K to activate the PDK1/Akt-dependent cell proliferation signaling in breast cancer. Theranostics 9: 7003-7015, 2019.

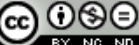

This work is licensed under a Creative Commons Attribution-NonCommercial-NoDerivatives 4.0 International (CC BY-NC-ND 4.0) License. 